Зарбалізаде Е., аспірант

Національний транспортний університет

м. Київ, Україна

DOI: https://doi.org/10.30525/978-9934-26-036-0-11

\title{
СУТНІСТЬ ГРОШОВИХ ВИТРАТ ПРИМІСЬКИХ ПАСАЖИРСЬКИХ ПЕРЕВЕЗЕНЬ
}

Затори у містах, негативний вплив від автомобілів на навколишнє середовище призводить до незадоволення населення великих міст та загрожує їх безпеці. Значну частку потоку автомобілів у великих мегаполісах утворюють приватні автомобілі мешканців передмість. На прикладі м. Києва це підтверджують експерти транспортної галузі [1].

Саме тому, актуальним $є$ вивчення факторів, що впливають на вибір водія щодо використання приватного автомобіля чи приміського пасажирського транспорту. Одним з таких факторів $\epsilon$ грошові витрати мешканця передмістя на приміські поїздки.

Структура прямих витрат водія залежить від типу і параметрів поїздок (приміські прямі, комбіновані 3 іншими видами транспорту, власним автомобілем, комбіновані з громадським транспортом), необхідності паркування, часу доби (година пікового навантаження або нічний час). Через це економічні мотиви людини до користування приватним автомобілем або громадським транспортом є складними та розгалуженими.

У більшості випадків водій-містянин враховує лише прямі витрати на поїздку (витрати 3 кишені). Інвестиційні витрати (ціна автомобіля, іiі зменшення внаслідок експлуатації, вартість страхування i технічного обслуговування) не враховуються. Людина не приділяє їм належної уваги як таким, що їх не можна уникнути. До того ж автомобіліст практично не зважає на соціальні та екологічні витрати, які є наслідком експлуатації автомобіля. Вони виникають тому, що суспільство втрачає час, коли автомобіль знаходиться на дорозі та утворюються затори. Викиди спричиняють шкоду довкіллю. Бюджети міст 
витрачаються на розбудову гіпертрофованої автомобільної інфраструктури, на відміну від гуманітарної сфери [2, с. 31].

Практичне втілення принципу «хто їде, той платить» при компенсуванні негативних соціальних та екологічних наслідків експлуатації автомобільного транспорту також може відбуватись за рахунок збільшення прямих витрат водіїв приватних автомобілів, як найбільш дієвого заходу управління їхньою транспортною поведінкою [2].

На противагу від міської поїздки, характеристики транспортної поведінки мешканців передмість залежать не лише від суми їхніх прямих витрат на подорож до міста власним автомобілем, а й від їхньої структури (розподілу за статтями) [2, с. 127-139]. Найбільший вплив тут все одно спричиняють поточні змінні витрати, які виплачуються «з кишені»: вартість палива, парковка, оплата в’їзу, плата за проїзд по дорозі. Менший вплив чинитимуть вартість технічного обслуговування, необхідність оплачувати заміну витратних матеріалів і деталей (літня і зимова гума), мийка. При цьому частину витрат водії сприймають, як більш справедливі (паливо), а інші, як такі, що дискримінують платний в’їз, парковка на вулиці (на відміну від критого паркінгу). Витрати-екстерналії, що виникають у приміському сполученні, також сплачуються не самими водіями, тож вони не беруть їх до уваги (протидію шкоді довкіллю, необхідність поліпшення інфраструктури, оплату запобігання негативним соціальним ефектам).

Загалом до структури витрат, які здійснює водій, увійдуть:

- змінні (паливо, паркування, оплата проїзду по дорозі, оплата в”ізду, мийка, періодичне технічне обслуговування);

- одноразові (вартість придбання автомобіля, податок при реєстрації, вартість реєстраційних процедур, оплата внаслідок нестрахової ДТП, вартість додаткового обладнання автівки, ремонт);

- умовно-постійні (оплата зберігання автівки - гаражу; страховка). 
За даними [2, с. 139] співвідношення прямих змінних та суми умовно-постійних і одноразових витрат у США виражається як $13 \%$ до $87 \%$. А покриття витрат на екологічні заходи та інфраструктуру оплачується лише частково, наприклад, у складі акцизу на паливо. Так, в Україні водії приватних автомобілів за рахунок оплати акцизу на паливо покривають за оцінками [1] лише близько 1\% собівартості утримання мережі доріг. Покриття всіх цих витрат автомобілістами США складає всього 8\%. Слід зауважити, що аналогічні надійні дані щодо вітчизняних реалій знайти не вдалося.

Розуміння структури витрат приміських перевезень дозволить прогнозувати транспорту поведінку приміських водіїв в залежності від зміни вартості поїздки приватним автомобілем та приміським транспортом.

\section{Література:}

1. Як Києву перемогти рекордні автомобільні затори: 5 болісних кроків. URL: https://www.epravda.com.ua/publications/2020/10/ 12/666146.

2. Вукан Р. Вучик. Транспорт в городах, удобных для жизни. Территория будущего, 2011. $576 \mathrm{c}$. 